\title{
Response of Bell Pepper Crop Fertigated with Nitrogen and Potassium Doses in Protected Environment
}

\author{
Marcelo Zolin Lorenzoni*, Roberto Rezende, Álvaro Henrique Cândido De Souza, Cássio De Castro Seron, Tiago Luan Hachmann and \\ Paulo Sérgio Lourenço De Freitas
}

‘State University of Maringá, Maringá, Paraná, Brazil.

\begin{abstract}
Bell pepper is among the ten most economically important vegetables in the country. The proper management of water and fertilizers coupled with protected environment allows to obtain a quality agricultural production. This study aimed to evaluate the response of nitrogen and potassium doses applied through fertigation on the growth and yield of bell pepper crop, Magali $\mathrm{R}$ hybrid. A completely randomized design was used, with 16 treatments in a factorial scheme $4 \times 4$, with four replications. The treatments resulted from the combination of four doses of nitrogen $(0 ; 73.4$; 146.8 and $\left.293.6 \mathrm{~kg} \mathrm{ha}^{-1}\right)$ and potassium $\left(0,53.3 ; 106.7\right.$ and $\left.213.4 \mathrm{~kg} \mathrm{ha}^{-1}\right)$. The experimental plot consisted of a $25 \mathrm{~L}$ pot with a bell pepper plant. Seven harvests were made throughout the experiment, and fresh fruit number and mass were evaluated. Leaf area (LA) and total matter accumulation were evaluated as growth components. Regardless of the applied potassium doses, the variables LA and total dry matter showed higher results for $\mathrm{N}$ ranging from 155 to $194 \mathrm{~kg} \mathrm{ha}^{-1}$. The maximum fresh fruit matter (FFM) (1882 $\left.\mathrm{g} \mathrm{plant}^{-1}\right)$ occurred at the dose of $155 \mathrm{~kg} \mathrm{~N} \mathrm{ha}^{-1}$ and 106.7 $\mathrm{kg} \mathrm{K} \mathrm{ha}^{-1}$ and the maximum number of fruits (NF) (16.3 fruits plant $\left.{ }^{-1}\right)$ was obtained at the dose of $147 \mathrm{~kg} \mathrm{~N} \mathrm{ha}^{-1}$ and $106.7 \mathrm{~kg} \mathrm{~K} \mathrm{ha}^{-1}$.
\end{abstract}

Keywords: Capsicum annuum L.; Mineral nutrition; Cultivation in pots; productivity; growth

\section{Introduction}

The bell pepper crop (Capsicum annuum L.) belongs to the Solanaceae family. In Brazil it is among the ten vegetables of greater economic and social importance. Its fruits have a high content of vitamin $\mathrm{C}$ and are consumed raw or ripe, and are used in the manufacture of condiments, pickles and sauces [20].

The use of bell pepper hybrid seeds and cultivation in protected environment are technologies that have been used to improve fruit quality and productivity. Among the vegetables conducted in protected cultivation, the main ones are peppers, tomatoes, cucumbers and leafy vegetables. The practice of cultivation in protected environment is a way to avoid the environmental adversities and may favor the production compared to the crop in the field, in addition to allowing increased cycle [2].

The bell pepper hybrid "Magali R" was released in 1995 and is able to combine productivity with oomycete resistance (Phytophthora capsici), better use of nutrients, easy adaptation to cultivation and marketing [3].

For good plant growth and to meet its nutritional and water needs in a protected environment, the use of irrigation systems is critical to enable higher frequency of irrigation and the use of fertigation [5]. Fertigation is a fertilizer application method along with irrigation water. It is an efficient technique of applying fertilizers to plants, allowing the use in smaller quantities at a time, as well as the ease incorporation of chemical in the ground, labor saving and convenience [15].

Nitrogen is the most important nutrient for bell pepper cultivation [6], and alongside with potassium, are the nutrients most required by the crop [7]. For this reason it is required greater attention with the supplementation of these nutrients. Almuktar et al. [8] noted the negative impacts on growth development of bell peppers, possibly due to the high concentrations of nutrients and minerals.
The information about the behavior and nutritional requirements of the bell pepper crop are based on work done in the field. Therefore it is fundamental to encourage research in order to generate information to help bell pepper producers make correct decisions regarding the conduction of the culture in protected cultivation.

Given the above, this study aimed to evaluate the growth and yield of bell pepper crop with different doses of nitrogen and potassium via fertigation in protected environment.

\section{Materials and Methods}

The experiment was conducted from February 2015 to August 2015 in a protected environment with the dimensions of $20 \mathrm{~m}$ long, $7 \mathrm{~m}$ wide and $3 \mathrm{~m}$ high, located in the Centro Técnico de Irrigação (CTI) of the State University of Maringá (UEM) in Maringá-PR, at the coordinates $23^{\circ} 25^{\prime} 57^{\prime \prime} \mathrm{S}, 51^{\circ} 57^{\prime} 08^{\prime \prime} \mathrm{W}$ and $542 \mathrm{~m}$ altitude. The climate, according to Köppen classification, is CFA Mesothermal Humid, abundant rainfall in the summer and dry winters. The average annual temperature is $21.8^{\circ} \mathrm{C}$.

The experimental design was completely randomized in a factorial $4 \times 4$ (four doses of $\mathrm{N}$ with 4 doses of $\mathrm{K}$ ), with four replications, totaling 64 experimental units. Each unit is represented by a pot containing a plant and arranged in five longitudinal lines inside the protected environment, spaced $1.2 \mathrm{~m}$ between rows and $0.5 \mathrm{~m}$ between plants.

*Corresponding author: Marcelo Zolin Lorenzoni, State University of Maringá Maringá, Paraná, Brazil, Tel: +55 044-99305034; E-mail: marcelorenzoni@ hotmail.com

Received July 16, 2016; Accepted August 25, 2016; Published September 02, 2016

Citation: Lorenzoni MZ, Rezende R, De Souza AHC, Seron CDC, Hachmann TL, et al. (2016) Response of Bell Pepper Crop Fertigated with Nitrogen and Potassium Doses in Protected Environment. Agrotechnology 5: 148. doi: 10.4172/21689881.1000148

Copyright: ( 2016 Lorenzoni MZ, et al. This is an open-access article distributed under the terms of the Creative Commons Attribution License, which permits unrestricted use, distribution, and reproduction in any medium, provided the original author and source are credited. 
The pots (Nutriplan ${ }^{\otimes}$ ) of $25 \mathrm{~L}$ volume were filled with $25 \mathrm{~kg}$ of soil classified as Dystrophic Red Latosol (Oxisol), sandy texture, collected from the layer 0.0 to $0.20 \mathrm{~m}$. The chemical characteristics were analyzed by the Laboratório Rural de Análise de Solos de Maringá and is shown in Table 1 . The drainage system consisted of $4 \mathrm{~kg}$ of $\mathrm{n}^{\circ} 1$ crushed stone, enough to fill the bottom of the pot. On top of the gravel layer, a nonwoven fabric disk was placed to avoid losing the finer fraction of the soil.

Liming was done 60 days before the transplantation, in order to raise soil base saturation up to $80 \%$. For planting fertilization, the fertilizers were mixed with the soil to homogenise the fertility condition, using $9.6 \mathrm{~g} \mathrm{~K} 2 \mathrm{O}$ per pot, $28.8 \mathrm{~g}$ of $\mathrm{P} 2 \mathrm{O} 5$ per pot and $500 \mathrm{~g}$ of organic matter per pot were applied 20 days before transplanting, following the recommendation of Trani PE [9.]

The treatments resulted from the combination of four nitrogen $\left(\mathrm{N} 1=0, \mathrm{~N} 2=73.4 ; \mathrm{N} 3=146.8\right.$ and $\left.\mathrm{N} 4=293.6 \mathrm{~kg} \mathrm{ha}^{-1}\right)$ and potassium doses $\left(\mathrm{K} 1=0, \mathrm{~K} 2=53.3\right.$; $\mathrm{K} 3=106.7$ and $\left.\mathrm{K} 4=213.4 \mathrm{~kg} \mathrm{ha}^{-1}\right)$, totaling 16 treatments, considering the maximum doses recommended by Trani $\mathrm{PE}$ [9], since there is no recommendation in the literature for the region in which this work was done. The amounts of nutrients were divided according to the absorption rate for bell pepper crop [10] and applied weekly via fertigation. The fertilizers used were urea Vitaplant ${ }^{\circ}$ $(45 \% \mathrm{~N} ; 26 \% \mathrm{O} ; 21 \% \mathrm{C}$ e $8 \% \mathrm{H})$ and potash Nutriplant ${ }^{\oplus}$ (60\% K; $28 \%$ $\mathrm{Cl} ; 12 \% \mathrm{O}$ ), because they are widely used.

Seedlings of bell pepper Magali R hybrid (Sakata Seed Sudameris) were produced in polyethylene trays Nutriplan ${ }^{\circ}$ with 64 cells filled with commercial substrate Mecplant ${ }^{\oplus}$ proper for vegetables and transplanted when they had four to six true leaves, at 34 days after sowing.

Drip irrigation system was used with a $4 \mathrm{~L} \mathrm{~h}^{-1}$ flow emitter in each experimental unit. The replenishment of the water was controlled by daily weighing of pots using a digital scale Multivisi ${ }^{\oplus}$ with capacity of $40 \mathrm{~kg}$. When soil moisture was approaching the critical moisture $(0.09 \mathrm{~g}$ $\left.\mathrm{g}^{-1}\right)$ the soil was irrigated until the moisture in the field capacity $\left(0.2 \mathrm{~g} \mathrm{~g}^{-1}\right)$.

Seven fruit harvests were performed during the experiment, the first held at 66 days after transplanting (DAT) and the last at 136 DAT. The chosen harvest stage was when the fruits had maximum visual development, before acquiring the characteristic color of the variety (red).

Leaf area (LA), measured in $\mathrm{cm}^{2}$ per plant, was quantified by the digital image method (Maller et al.) [11]. Total dry matter, without fruits, in grams per plant, was quantified when the samples, dried in an air circulation stove at $65^{\circ} \mathrm{C}$, acquired constant mass.

Production variables were fresh mass and the number of commercial fruits. The fruits were classified as commercial when presented diameter and length greater than 4 and $6 \mathrm{~cm}$, respectively, and unmarketable fruits those which had serious defects or different dimensions from the ones mentioned. The measures of length and diameter of fruit were taken with a digital caliper $\mathrm{Mtx}^{\oplus}$. The fresh mass measurements were obtained using a digital scale Marte UX6200H with capacity of $6200 \mathrm{~g}$

The data were submitted to analysis of variance, at 1 and $5 \%$ probability, applying the $\mathrm{F}$ test. In case of significant interaction between levels, unfolding and study of regression took place, considering the linear and quadratic models. Statistical analyzes were performed using the statistical software Sisvar [12].

\section{Results And Discussion}

There was a significant interaction between nitrogen and potassium levels $(p<0.01)$ for the variables LA, total dry matter (TDM), fresh fruit mass (FFM) and NF of the bell pepper plants (Table 2).
According to the unfolding of the $\mathrm{N}$ and $\mathrm{K}$ factors, for the variable LA, significant differences were found for the nitrogen doses in all potassium levels. Regarding potassium doses, there were significant differences in levels N2, N3 and N4. The quadratic model showed the best fit to the data for the application of nitrogen (Figure 1A). The increasing linear model presented better fit for the application of potassium in N2 and N3 levels, while the decreasing linear model showed the best fit for the N4 level (Figure 1B). Nitrogen doses above $220 \mathrm{~kg} \mathrm{ha}^{-1}$ can cause disequilibrium with other macro or micronutrient with negative effects [13], which may be related to the decrease in LA value for all cases in which the highest dose of nitrogen was applied.

Larger LA values were obtained between nitrogen doses ranging from 155 to $173 \mathrm{~kg} \mathrm{ha}^{-1}$, regardless of level of potassium applied via fertigation. The maximum value of LA $\left(7999.3 \mathrm{~cm}^{2}\right.$ per plant $)$ was estimated at K4 level (213.4 $\left.\mathrm{kg} \mathrm{ha}^{-1}\right)$, requiring $155.3 \mathrm{~kg} \mathrm{ha}^{-1}$ of nitrogen. With regard to the potassium application, the maximum value of LA $\left(7840 \mathrm{~cm}^{2}\right.$ plant $\left.^{-1}\right)$ was estimated at the dose of $213.4 \mathrm{~kg} \mathrm{~K} \mathrm{ha}^{-1}$ and applying $146.8 \mathrm{~kg} \mathrm{~N} \mathrm{ha}^{-1}$ (Figure 1B).

Aragão et al. (2011) [1], studying the effect of different irrigation depths and nitrogen levels in bell pepper, Magali R cultivar, observed that in most applied depths LA increases with the increase in the dose of $\mathrm{N}$ [14], working with different managements of fertigation in bell pepper, observed that the LA presented a quadratic response with increasing $\mathrm{N}$ and $\mathrm{K}$ levels.

For the TDM variable, there were significant differences in the application of nitrogen at each level of the $\mathrm{K}$ factor. Subjected to regression analysis the TDM data showed better adjustment to the quadratic model (Figure 2A). With application of potassium there were significant differences for the N2, N3 and N4 levels. There were no significant differences for N1. This may be related to the application of $\mathrm{K}$ associated with the low amount of $\mathrm{N}$, reducing dry mass production. $\mathrm{N} 2$ and N3 levels were better adjusted to the quadratic model, while the N4 level showed decreasing linear trend with increasing $\mathrm{K}$ doses (Figure 2B)

Larger TDM values were obtained within the range 162 to 194 $\mathrm{kg} \mathrm{N} \mathrm{ha}^{-1}$ (Figure 2A). Aragão et al. [1] verified an increase in TDM production with the increase in nitrogen doses.

For the potassium doses, the maximum value of TDM $(66.7 \mathrm{~g}$ plant $^{-1}$ ) was found with the dose of $131 \mathrm{~kg} \mathrm{~K} \mathrm{ha}^{-1}$ for N3 level (Figure 2B). Oliveira et al. [14] had a decrease in the production of TDM from $200 \% \mathrm{~N}$ and $\mathrm{K}$ with bell pepper crop undergoing different fertigation managements. This effect can be attributed to increased salinity of the soil above the tolerated by the crop resulting from the accumulation of ions in the soil due to the application of high amounts of nitrogen and potassium.

The variable FFM presented quadratic trend for the application of nitrogen and potassium, with the exception of the N1 and N4 levels which did not differ with the application of different doses of potassium (Figure 3). According to Malavolta [13] the excess nitrogen can cause reduction in fructification, directly affecting productivity.

The highest FFM value (1882 $\mathrm{g} \mathrm{plant}^{-1}$ ) was achieved with $106.7 \mathrm{~kg}$ $\mathrm{K} \mathrm{ha}^{-1}$ and $155 \mathrm{~kg} \mathrm{~N} \mathrm{ha}^{-1}$. On average, the amount of nitrogen required to obtain maximum FFM, regardless of the $\mathrm{K}$ level applied, was set between the doses 155 to $168 \mathrm{~kg} \mathrm{ha}^{-1}$. Almuktar and Scholz [16] reported that with increasing nitrogen on bell pepper led increases total yield.

Regarding potassium fertigation, higher FFM values were found at the doses of $118 \mathrm{~kg} \mathrm{ha}^{-1}$ for the N2 level and $115 \mathrm{~kg} \mathrm{ha}^{-1}$ for the N3 
Citation: Lorenzoni MZ, Rezende R, De Souza AHC, Seron CDC, Hachmann TL, et al. (2016) Response of Bell Pepper Crop Fertigated with Nitrogen and Potassium Doses in Protected Environment. Agrotechnology 5: 148. doi: 10.4172/2168-9881.1000148

Page 3 of 5

\begin{tabular}{|c|c|c|c|c|c|c|c|c|c|c|c|}
\hline \multirow[t]{2}{*}{ pH } & O.M. & $\mathbf{P}$ & $\mathrm{Na}^{+}$ & $\mathbf{K}^{+}$ & $\mathrm{Ca}^{+2}$ & $\mathrm{Mg}^{+2}$ & $\mathrm{Al}^{+3}$ & $\mathrm{H}^{+}$ & Sand & Silt & Clay \\
\hline & $\mathrm{g} \mathrm{dm}^{-3}$ & \multicolumn{2}{|c|}{$----\mathrm{mg} \mathrm{dm}^{-3}$---- } & \multicolumn{5}{|c|}{$\mathrm{cmol}_{\mathrm{c}} \mathrm{dm}^{-3}$} & \multicolumn{3}{|c|}{ g kg } \\
\hline 4.8 & 4.66 & 8.63 & 2.1 & 0.07 & 1.56 & 0.38 & 0.7 & 2.48 & 780 & 30 & 190 \\
\hline
\end{tabular}

Table 1: Chemical characteristics of the soil used in the experiment.

\begin{tabular}{|c|c|c|c|c|}
\hline \multirow{2}{*}{$\begin{array}{l}\text { Variation } \\
\text { sources }\end{array}$} & \multicolumn{4}{|c|}{ Variables } \\
\hline & LA & TDM & FFM & $\mathrm{NF}$ \\
\hline & \multicolumn{4}{|c|}{$F$ values } \\
\hline Nitrogen $(\mathrm{N})$ & 673.389 ** & 501.138 ** & 388.512 ** & 167.722 ** \\
\hline Potassium (K) & $25.144^{* *}$ & $2.336^{\text {ns }}$ & 61.239 ** & 18.354 ** \\
\hline $\mathrm{N} \times \mathrm{K}$ & $17.841^{* *}$ & $11.375^{* *}$ & $13.934^{* *}$ & 5.949 ** \\
\hline $\mathrm{N} \times \mathrm{K} 1$ & $91.616^{* *}$ & 101.042 ** & 50.982 ** & $27.646^{* *}$ \\
\hline $\mathrm{N} \times \mathrm{K} 2$ & $127.045^{* *}$ & 115.343 ** & 84.400 ** & 30.861 ** \\
\hline $\mathrm{N} \times \mathrm{K} 3$ & $197.085^{* *}$ & $180.408^{* *}$ & 227.441 ** & $90.203^{* *}$ \\
\hline $\mathrm{N} \times \mathrm{K} 4$ & 311.166 ** & 138.470 ** & $67.491^{* *}$ & $36.861^{* *}$ \\
\hline $\mathrm{K} \times \mathrm{N} 1$ & $0.351^{\text {ns }}$ & $0.305^{\mathrm{ns}}$ & $0.758^{\text {ns }}$ & $1.291^{\mathrm{ns}}$ \\
\hline $\mathrm{K} \times \mathrm{N} 2$ & 29.736 ** & $10.047^{* *}$ & 35.736 ** & 22.481 ** \\
\hline $\mathrm{K} \times \mathrm{N} 3$ & $44.316^{* *}$ & $9.319 * *$ & 65.832 ** & $10.608^{* *}$ \\
\hline $\mathrm{K} \times \mathrm{N} 4$ & $4.262^{* *}$ & 16.791 ** & $0.715^{\mathrm{ns}}$ & $1.823^{\mathrm{ns}}$ \\
\hline CV (\%) & 10.97 & 9.19 & 6.88 & 8.41 \\
\hline General average & 3521.83 & 41.20 & 1057.22 & 10.78 \\
\hline
\end{tabular}

"Significant at $1 \%$ probability; " Significant at $5 \%$ probability; ns not significant

Table 2: Summary of the analysis of variance for leaf area (LA), total dry matter (TDM), fresh fruit mass (FFM) and number of fruits (NF) in bell pepper, fertigated with doses of nitrogen and potassium, cultivated in a protected environment.
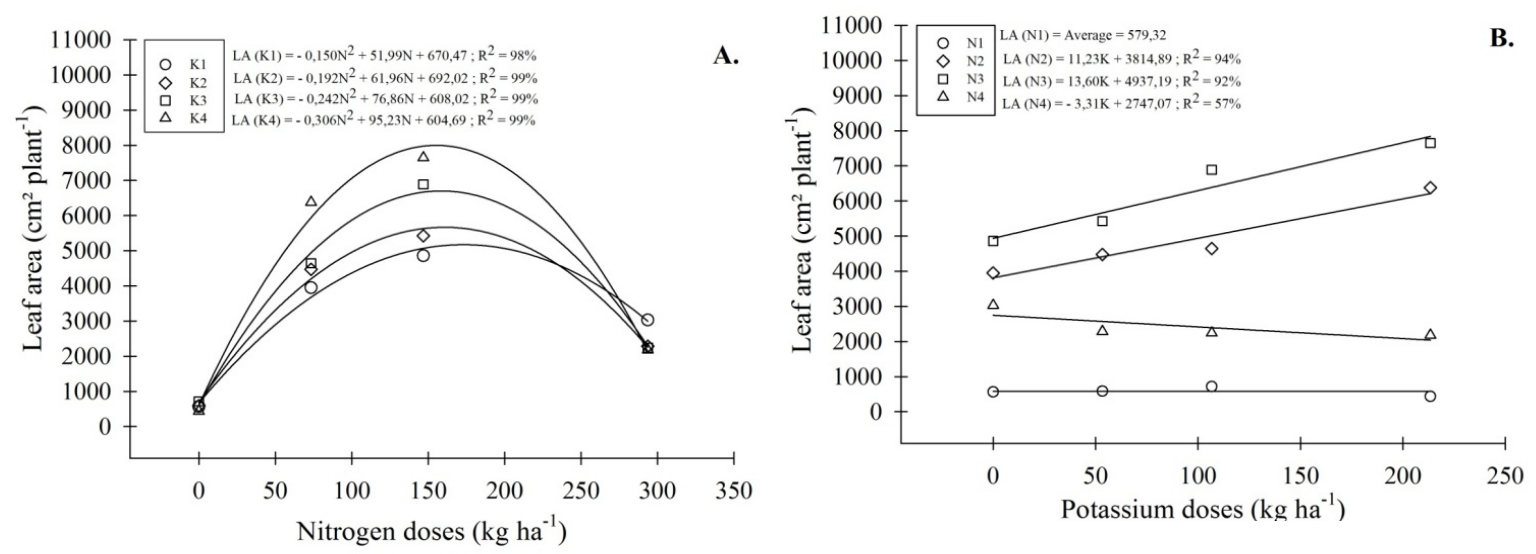

Figure 1: Unfolding of the $\mathrm{N} \times \mathrm{K}$ interaction for the variable LA for bell pepper crop. Nitrogen doses in the $\mathrm{K}$ factor levels (A) and potassium doses in the $\mathrm{N}$ factor levels (B).
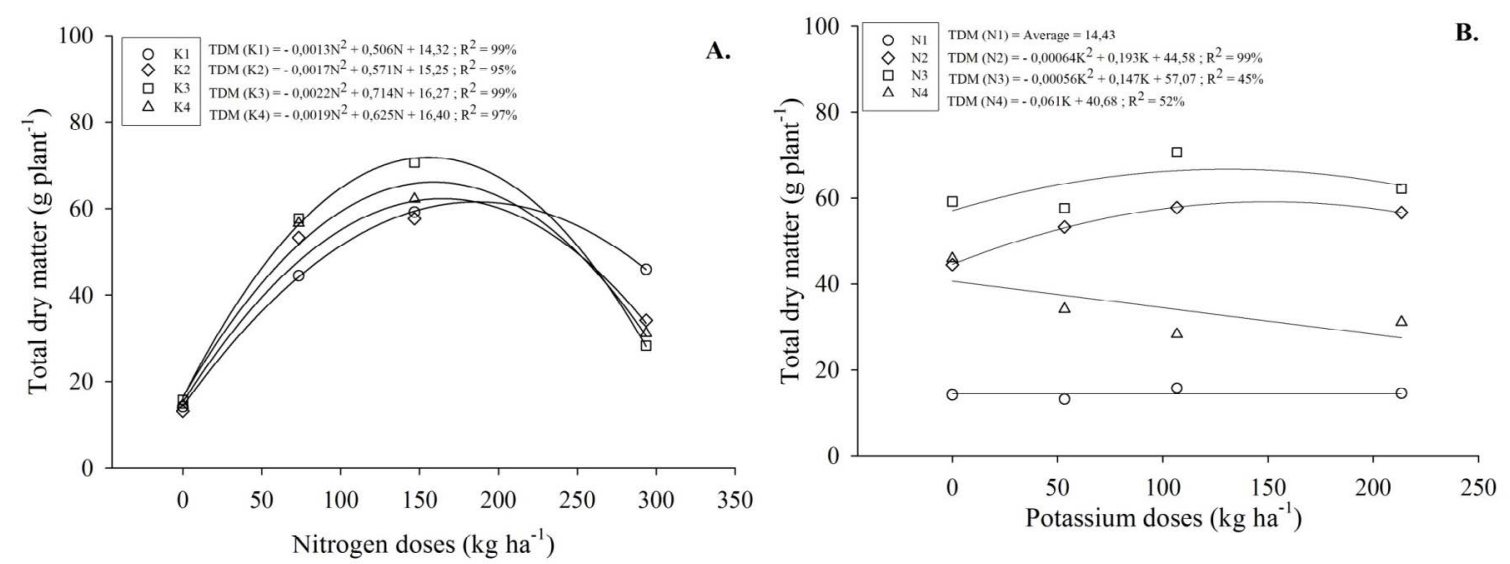

Figure 2: Unfolding of the $\mathrm{N} x \mathrm{~K}$ interaction for the variable TDM for bell pepper crop. Nitrogen doses in the $\mathrm{K}$ factor levels (A) and potassium doses in the $\mathrm{N}$ factor levels (B). 
level (Figure 3B). According to Oliveira et al. [14], the reduction of the production of fruits per plant, when doses above the one which provided maximum performance were administered, can be attributed to the toxic effect of the fertilizers in the soil, resulting in reduced absorption of water and nutrients by plants.

It is possible to find in the literature studies that reported positive effect of fertilization with nitrogen and potassium on the yield of bell pepper crop, with linear or quadratic response [5,17-19].

For the variable NF, the unfolding of the $\mathrm{N}$ and $\mathrm{K}$ factors showed significant differences for nitrogen application at $\mathrm{K}$ levels, while for potassium application there were significant differences only in $\mathrm{N} 2$ and N3 levels, similar to what occurred to the FFM variable.

The fruits number data presented quadratic adjustment for nitrogen doses in all $\mathrm{K}$ levels and for potassium doses in N2 and N3 levels (Figure 4). This result was also verified by Melo et al. [5] who obtained quadratic adjustment for NF in relation to the application of potassium doses in the production of bell pepper fruits. Campos et al. [19] and Oliveira et al. [14] also found quadratic response for the NF variable due to the application of nitrogen and potassium.

The dose of nitrogen that promoted the greatest commercial NF (16.3 fruits per plant) was $147 \mathrm{~kg} \mathrm{ha}^{-1}$ for K3 level, whereas the dose of potassium which provided the highest commercial NF (16.1 fruits per plant) was $128 \mathrm{~kg} \mathrm{ha}^{-1}$ for $\mathrm{N} 2$ level. Campos et al. [19] obtained higher value than the ones found in this study, for bell pepper cultivation, cultivar All Big, with 44 fruits per plant at a dose of $252 \mathrm{~kg} \mathrm{ha}^{-1}$ of nitrogen.

According to Malavolta [13] excess of nitrogen (doses above $220 \mathrm{~kg}$ $\mathrm{ha}^{-1}$ ) can cause reduction in fructification (Figure $4 \mathrm{~A}$ ), while the lack of potassium (doses below $60 \mathrm{~kg} \mathrm{ha}^{-1}$ ) reduces the NF (Figure 4B).

The NF in this study was higher than that found by Araújo et al. [18-20]. These authors found higher commercial NF (12.8 fruits per plant) with the application of the maximum dose of $\mathrm{N}\left(400 \mathrm{~kg} \mathrm{ha}^{-1}\right)$.

Melo et al. [5] evaluating the effect of potassium doses in bell pepper crop obtained the maximum of three fruits per plant at the dose of $10 \mathrm{~g}$ per pot. Albuquerque et al. [4], studying the effects of different irrigation levels and potassium doses on the growth and yield of bell pepper, obtained an average of 6.5 fruits plant- 1 at doses of 80 and $120 \mathrm{~kg} \mathrm{ha}^{-1}$.

The literature shows great variability in the NF in bell pepper crop that may be related to the lack of standardization of the number of harvests, cultivar or spacing used, nutritional management, conduction system and climate, which affects the number of harvested fruits.

The variables LA, TDM, FFM and NF were influenced by the application of nitrogen and potassium doses showing the interaction
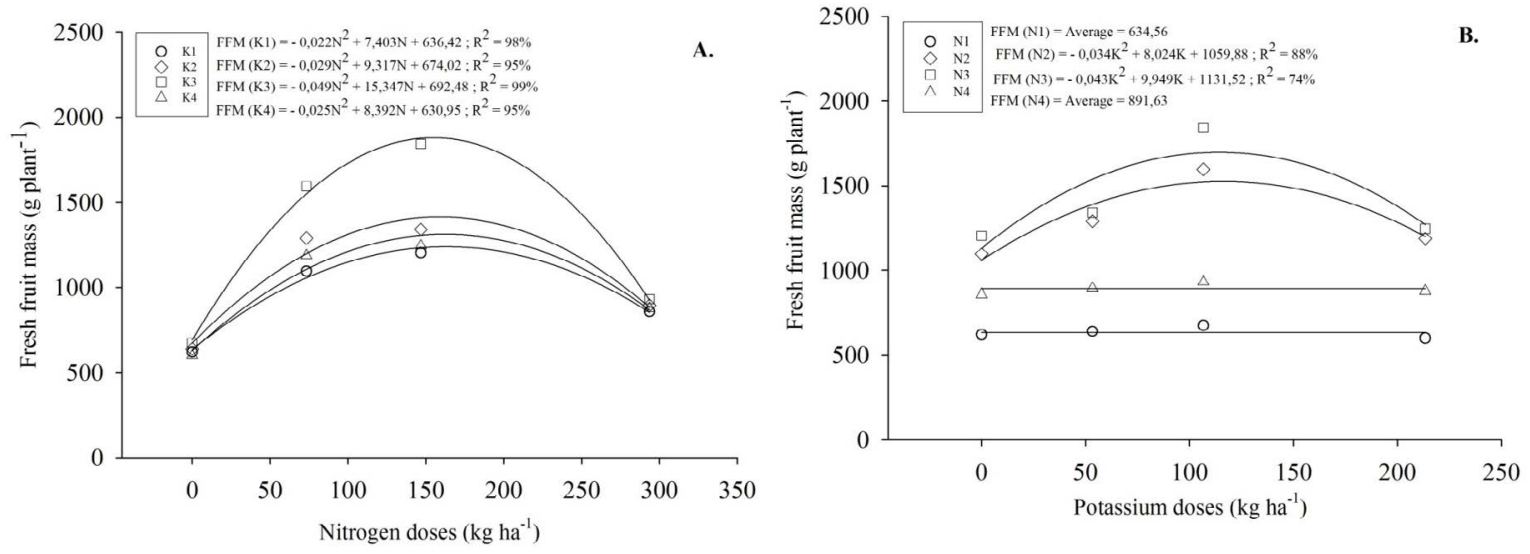

Figure 3: Unfolding of the $\mathrm{N} \times \mathrm{K}$ interaction for the variable FFM for bell pepper crop. Nitrogen doses in the $\mathrm{K}$ factor levels (A) and potassium doses in the $\mathrm{N}$ factor levels (B).
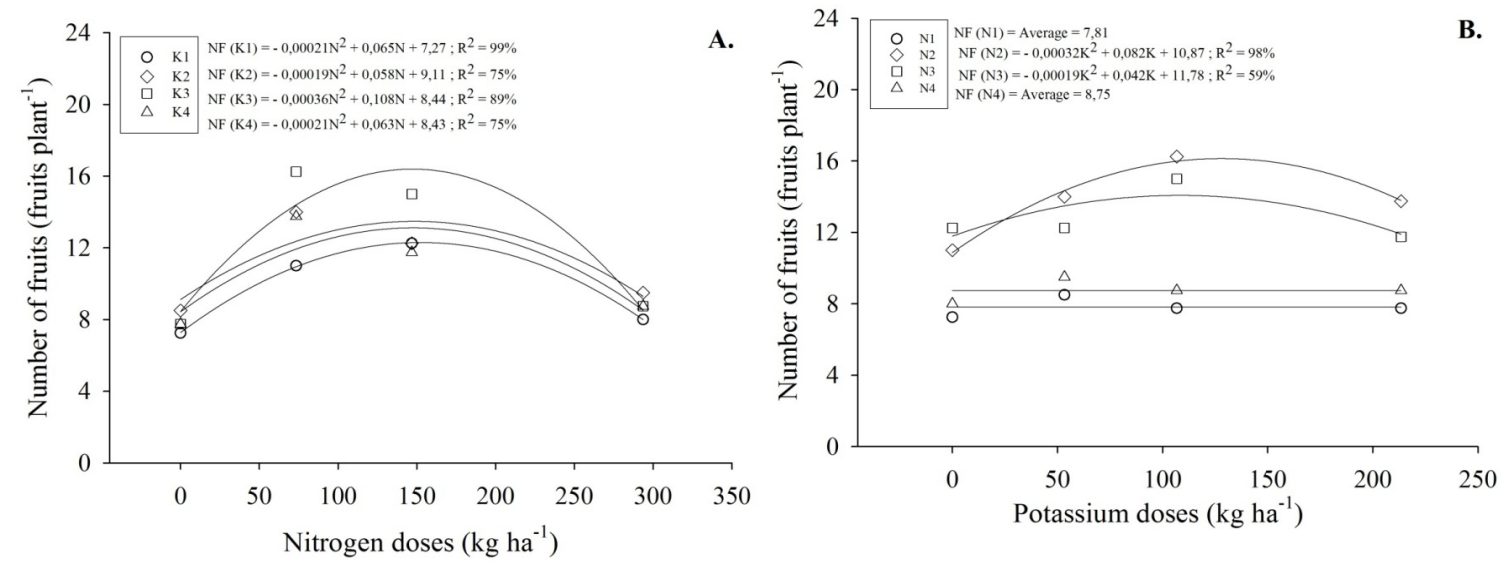

Figure 4: Unfolding of the $\mathrm{N} \times \mathrm{K}$ interaction for the variable NF for bell pepper crop. Nitrogen doses in the $\mathrm{K}$ factor levels (A) and potassium doses in the $\mathrm{N}$ factor levels (B). 
Citation: Lorenzoni MZ, Rezende R, De Souza AHC, Seron CDC, Hachmann TL, et al. (2016) Response of Bell Pepper Crop Fertigated with Nitrogen and Potassium Doses in Protected Environment. Agrotechnology 5: 148. doi: 10.4172/2168-9881.1000148

Page 5 of 5

of these fertilizers in the responses of the variables. Regardless of the potassium dose, the largest LA and TDM values were obtained by nitrogen fertilization with doses ranging from 155 to $194 \mathrm{~kg} \mathrm{ha}^{-1}$. The combination of the doses of 155 and $106.7 \mathrm{~kg} \mathrm{ha}^{-1}$ of nitrogen and potassium, respectively, promoted higher production of FFM in bell pepper (1882 grams per plant) and the dose of $147 \mathrm{~kg} \mathrm{ha}^{-1}$ of nitrogen and $106.7 \mathrm{~kg} \mathrm{ha}^{-1}$ of potassium promoted the maximum NF per plant (16.3).

\section{Acknowledgement}

The Coordenação de Aperfeiçoamento de Pessoal de Nível Superior (CAPES) and State University of Maringá (UEM).

\section{References}

1. Aragão VF, Fernandes PD, Gomes RR, Santos Neto AM, Carvalho CM, et al. (2011) Effect of different irrigation and nitrogen levels in the vegetative phase pepper in a protected environment. RBAI 5: 361-375

2. Lorentz LH, Lúcio AD (2009) Plot size and shape for chili pepper in plastic greenhouse. Rural science 39: 2380-2387.

3. Blat SF, Braz LT, Arruda AS (2007) Evaluation of sweet pepper hybrids. Brazilian horticulture 25: 350-354

4. Albuquerque FS, Silva EFF, Albuquerque Filho JAC, Nunes MFN (2011) Growth and yield of pepper fertigated under different irrigation depths and potassium doses. Agriambi 15: 686-694.

5. Melo AS, Brito MEB, Dantas JDM, Silva Júnior CD, Fernandes PD, et al. (2009) Yellow pepper yield and quality under potassium levels in a greenhouse. RBCA 4: 17-21.

6. Aragão VF, Fernandes PD, Gomes Filho RR, Carvalho CM, Feitosa HO, et al. (2012) Production and efficiency in water use of chili submitted to different irrigation levels and nitrogen levels. RBAI 6: 207-216

7. Epstein E, Bloom AJ (2006) Plants Mineral Nutrition : Principles and Perspectives. Plant, Londrina, Paraná.

8. Almuktar SAAAN, Scholz M, Al-Isawi RHK, Sani A (2015) Recycling of domestic wastewater treated by vertical-flow wetlands for irrigating chillies and sweet peppers. Agric Water Manage 149: 1-22
9. Trani PE (2014) Liming and fertilization for vegetables under protected cultivation . Agronomic Institute of Campinas, Campinas, Sao Paulo.

10. Fontes PCR, Dias EN, Graça RN (2005) Nutrient uptake curves and a method to estimate nitrogen and potassium rates in sweet pepper fertigation. Brazilian Horticulture 23: 275-280.

11. Maller A, Rezende, Freitas PSL, Hara AT, Oliveira JM (2013) Comparison between leaf area predictive models using zucchini var. Novita plus. Encyclopedia Biosphere 9: 71-81.

12. Ferreira, DF (2008) Sisvar: a program for analysis and statistics education. Rev Scientific Symposium 6: 36-41.

13. Malavolta E (2006) Manual of plants mineral nutrition. Agronomic Publishing Ceres, São Paulo, São Paulo.

14. Oliveira, A. F. ; Duarte, S. N .; Medeiros, J. F .; Dias, N. S .; Silva, A. C. P, et al . (2013) Management of fertigation and doses of $\mathrm{N}$ and $\mathrm{K}$ in the cultivation of pepper in greenhouse. Agriambi 17: 1152-1159.

15. Frizzone JA Freitas PSL, Rezende, Faria MA (2012) micro irrigation : drip and micro sprinkler. Eduem, Maringa, Parana.

16. Almuktar SAAAN, Scholz M (2016) Experimental assessment of recycled diese spill-contaminated domestic wastewater treated by reed beds for irrigation of sweet peppers. International journal of environmental research and public health 13: 1-20.

17. Marcussi FFN, Godoy LG, Villas Boas RL (2004) Nitrogen and potassium fertigation in sweet pepper culture based on $\mathrm{N}$ and $\mathrm{K}$ accumulation by plants. Irriga 9: 41-51.

18. Araújo JS, Andrade AP, Ramalho Cl , Azevedo CAV (2009) Characteristics of bell pepper fruits cultivated in greenhouse under doses of nitrogen via fertigation. Agriambi 13: 152-157.

19. Campos VB , Oliveira AP , Cavalcante LF , Prazeres (2008) Yield of pepper submitted at nitrogen applied through irrigation water in protected environment. Journal of Biology and Earth Science 8: 72-79.

20. Carvalho, JA, Rezende FC, Aquino RF, Freitas WA, Oliveira EC (2011) Productive and economic analysis of red-pepper under different irrigation depths cultivated in greenhouse. Agriambi 569-574. 